\title{
熱画像を用いた人物全身像の実時間姿勢推定
}

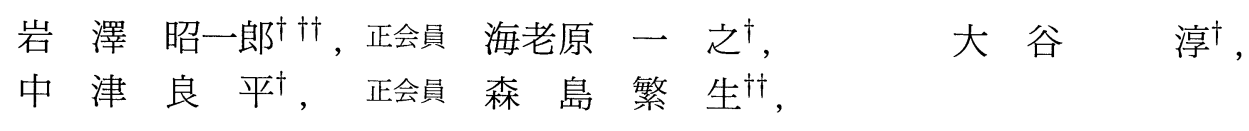

\section{Real-Time Estimation of Human Body Postures from Monocular Thermal Images}

\author{
Shoichiro Iwasawa ${ }^{\dagger \dagger}$, Kazuyuki Ebihara ${ }^{\dagger}$, Jun Ohya ${ }^{\dagger}$, \\ Ryohei Nakatsu ${ }^{\dagger}$ and Shigeo Morishima ${ }^{\dagger \dagger}$
}

\begin{abstract}
This paper proposes a new real-time method for estimating human body postures from thermal images acquired by an infrared camera, regardless of the background and lighting conditions. Distance transformation is performed for the human body area extracted from the thresholded thermal image, in order to calculate the center of gravity. After the orientation of the upper half of the body is obtained by calculating the moment of inertia, significant points such as the top of the head and the ends of the hands and feet are heuristically located. In addition, the elbow and knee positions are estimated from the detected (significant) points, using a genetic-algorithm-based learning procedure. The experimental results demonstrate the robustness of the proposed algorithm and real-time performance (faster than 20 frames per second).
\end{abstract}

\section{1. まえ がき}

人物の動作解析に関する研究が, コンピュータビジョ ンの分野で近年活発になっている．特に，人物の姿勢 推定処理はコンピュータとの将来型のインタフェース だけでなく，映画におけるコンピュータグラフィック スキャラクタ作成の省力化や, 仮想環境におけるキャ ラクタの動きの自動入力処理 ${ }^{1)}$ として, 期待が大きい.
本論文では，背景・照明条件等への制限がない一般的 な環境において，人物に特殊な負担を課すことなく， 人物全身像の姿勢を実時間で推定することが可能な手 法の検討を行う.

人物の姿勢や動作を計測する方法は接触型と非接触 型に大別できる．接触型とはデータグローブや磁気セ ンサなどのデバイスを身体に装着する形態のものであ り, 近年比較的簡単に利用可能になってきており, 計

キーワード：熱画像，姿勢推定，人物像処理，遺伝的アルゴリズム，実時間

1996 年 9 月 27 日, 電子情報通信学会画像工学研究会に概要を発表

1997 年 1 月 21 日受付, 1997 年 4 月 14 日再受付

$\dagger$ ATR 知能映像通信研究所 (T 619-02 京都府相楽郡精華町光台 2-2, TEL 0774-95-1401)

†† 成蹊大学 工学部 (广 180 武蔵野市吉祥寺北町 3-3-1, TEL 0422-37-3726)

$\dagger$ ATR Media Integration \& Communications Research Laboratories (2-2 Hikaridai, Seika-cho, Soraku-gun, Kyoto 619-02, Japan) $\dagger \dagger$ Faculty of Engineering, Seikei University (3-3-1 Kichijoji Kita-machi, Musashino-shi, Tokyo 180, Japan) 
測精度も高い。しかし，センサデバイスの装着は利用 者のストレス増大を招いたり，応用範囲の制限につな がる。また高反射素材のマーカを身体各部に貼付けて その動きを複数カメラにより追跡する手法があるが， やはり身体に物理的な拘束を伴う。

一方, 非接触型には, 一般に画像などから得られる 情報に基づいて人物動作を獲得するというアプローチ があり, 接触型計測に比べ利用者への負担が軽減され るという利点がある。特に，均一色の背景を用意し， クロマキーにより人物像を実時間で抽出する方式は映 像編集の分野等で実用に供されているが，特殊な背景 が使用できない一般的な環境への適用は困難である. 画像から人物動作の検出・認識を行う従来の研究とし ては, 静止画像から人体姿勢の記述を得ようとする試

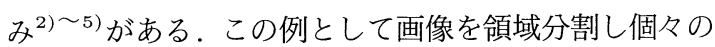
領域を動的輪郭モデルにより近似する手法 ${ }^{4) 6}$ がある が, 距離画像が必要となるため実用的ではない. 対象 に依存せず関節物体の姿勢の推定を行う例 ${ }^{57)}$ では，あ らかじめ推定対象物体をモデル化しておく必要がある ため，任意の人物を対象とする場合などに課題が残る. また，時系列単眼画像中の人物動作を追跡する場合， 拘束条件あるいは人体各部の動作に関する知識を導入 したモデルとのマッチングを行う例 ${ }^{6) 8(8)}$ が多く見られ る. 知識や拘束条件により 3 次元動作を扱うことがで きるが, 任意の実画像に対して拘束条件を適用するこ とは容易ではない，また，ある時点の姿勢を推定する ためには過去の画像系列が必要不可欠である. 複数力 メラ画像を用いた 3 次元姿勢の推定 ${ }^{10) 11)}$ では計算コス トが膨大になる傾向があり, オフライン処理が妥当と 思われる。一方, 実時間性を追求した手法としては, 例えばWren らの提唱する Pfinder ${ }^{12)}$ がある. Pfinder では輪郭と色情報を解析し予測フィルタを用いて頭や 手足の追跡を実現している。しかし，扱える全身姿勢 の自由度が低く, 照明や背景, 衣服の色に処理結果が 大きく影響される等の問題点が挙げられる.

本論文で提案する手法では, 非接触かつ実時間での 人物全身像の姿勢推定の実現を目指し, 赤外線カメラ により入力される熱画像から照明条件や背景, 衣服の 色彩によらず安定して人物領域を抽出し, その輪郭を 解析することにより手先等の特徵点の位置を求める. 次に, 推定された特徵点の位置から, 遺伝的アルゴリ ズム $\left(\mathrm{GA}\right.$; Genetic Algorithm) ${ }^{13)}$ を利用した学習に より肘等の関節位置を推定する.

以下, 姿勢推定アルゴリズムの概要を 2 章に, 3 章 で特徴点の検出について述べ, 4 章では GA を用いて 时・膝位置を推定する手法を説明する。そして 5 章に

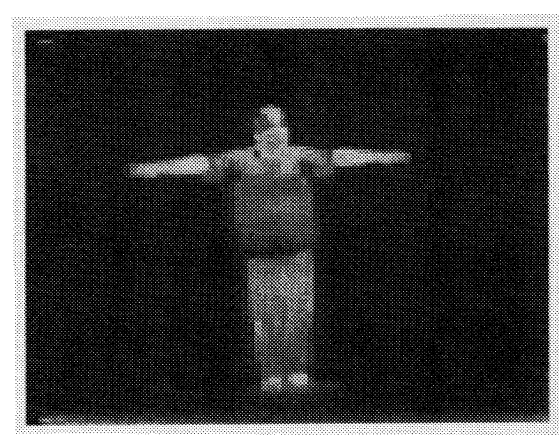

図 1 キャリブレーションのための姿勢

A posture used in the calibration.

扔いて提案手法による実験結果を示す.

\section{2. 姿勢推定処理の概要}

本論文において姿勢推定とは, 人物の手先等の特徵 点と时および膝関節の熱画像平面上での位置情報を求 めることを指す．以下では画像の左下隅を原点として 水平右向き，垂直上向きをそれぞれ正方向に座標系を 定義する。

本推定法では, まず, 赤外線カメラによって姿勢推 定の対象となる人物をビデオレートで撮影し時系列の 熱画像を得る。そして各フレームにおける熱画像から， 特徵点（頭頂, 手先, 足先）の位置検出を以下に示す 手順で進める.

（1）熱画像から人物のシルエットを抽出し距離変 換を行った後, 身体重心を求める。

（2）上半身距離画像の主軸方向を計算し, 上半身 の傾き角を得る。

（3）特徵点位置をシルエットの輪郭情報から人物 像の形状に関する事前知識に基づいて求める.

初期フレームに扔いて姿勢推定に先立ち, キャリブ レーションを行う。キャリブレーションの姿勢は図 1 に示すように直立した状態で, 両手を左右に広げて水 平に保つものである.この姿勢に対して 3 章で述べる 処理を施し, 特徵点の位置を求める. 推定処理の過程 において逐次参照するため, 人物のシルエット領域へ の外接四角形の高さと各特徵点の位置を初期值として 保持しておく.

特徵点の位置を求めた後, 肘および膝関節の位置を 推定する。これら関節位置は, 既知である特徵点位置 を, あらかじめGAによって決定された推定式に代入 することによって計算する。 


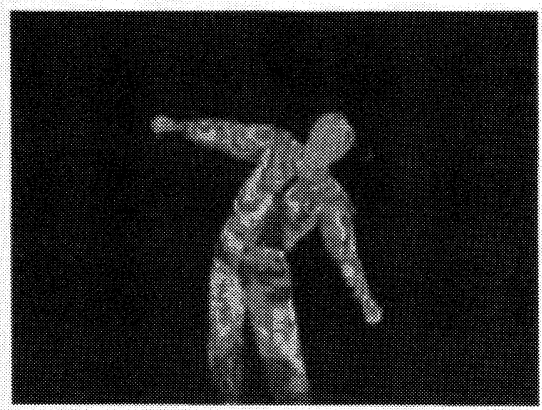

図 2 熱画像の例

An example of a thermal image.

\section{3. 特徵点の検出処理}

\section{1 身体重心点}

一般に, 可視光画像を用いて任意の背景・照明・服 装条件下のシーンから人物シルエット領域を安定かつ 高速に抽出することは困難である。前述の条件が変化 すると画像の輝度や色彩情報がその影響を受け易いた めである。本推定法では通常の室内環境を対象とし， 特別な背景や照明装置を用いず安定に人物シルエット を得るため赤外線カメラを用いる。

赤外線カメラは, 観測しているシーン中の物体が放 射する熱エネルギーを検出することにより，画素の值 が温度值である熱画像の入力を行う。したがって, 赤 外線力メラによりシーン中の人物を観測することによ り得られる熱画像においては，一般に図 2 に示すよう に人物の表面温度 (以下, 人物温度) と, 背景の温度 とが異なるため簡単な閾值処理により, 安定に人物像 に対応する領域の抽出が可能である。すなわち, 通常 の空調の作動している室内であれば人物温度以上の部 分はほとんど存在せず, また存在しても人物領域に比 べて微小な面積である。また人物によって人物温度は 異なることが予想されるが, 背景温度との差と比較し てその変動は非常に小さいために, 人物毎に人物温度 を再調整する必要は通常認められない.

赤外線力メラにより得られる熱画像を閾值処理する ことにより得られる 2 值画像をシルエット画像 $\left\{f_{i j}\right\}$ と呼ぶことにする。 $i, j$ は画像上でそれぞれ水平, 垂 直位置を示す．ここで $f_{i j}=1$ であるような画素集合 は人物シルエットを含んでおり，また $f_{i j}=0$ は背景 領域に相当する。

腕や脚等の姿勢に関わらずシルエットから身体重心 を安定に求めるために, 画像 $\left\{f_{i j}\right\}$ 上の $f_{i j}=1$ な る画素に対し距離変換 ${ }^{14)}$ を施す。距離変換された画像 $\left\{d_{i j}\right\}$ （図 3）の各画素 $d_{i j}$ は最近傍のシルエット境

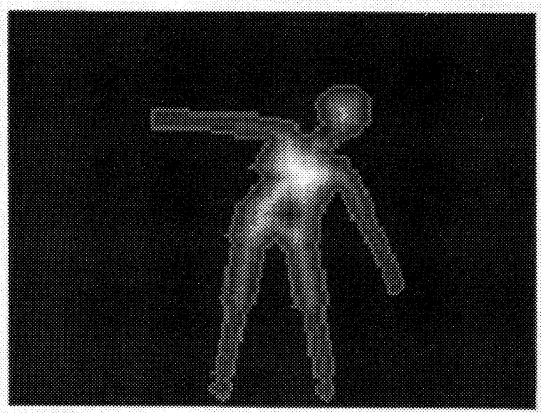

図 3 距離変換画像とシルエット輪郭 A distance-transformed image with a silhouette contour.

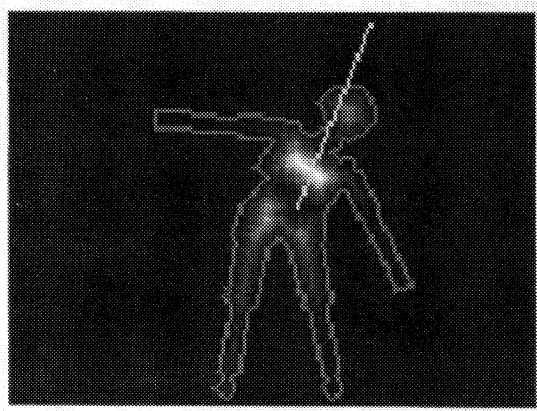

図 4 上半身距離画像 A distance-transformed upper half of the body image with PAU.

界画素までの距離を画素值として保持している。シル エットの重心 $\left(I_{\mathrm{c}}, J_{\mathrm{c}}\right)$ は次式を用いて求める.

$$
\begin{array}{r}
I_{\mathrm{c}}=\mathcal{M}\left(\left\{d_{i j}\right\}, 1,0\right) / \mathcal{M}\left(\left\{d_{i j}\right\}, 0,0\right) \\
J_{\mathrm{c}}=\mathcal{M}\left(\left\{d_{i j}\right\}, 0,1\right) / \mathcal{M}\left(\left\{d_{i j}\right\}, 0,0\right) \\
\text { ここで} \mathcal{M}\left(\left\{I_{i j}\right\}, p, q\right) \text { は }
\end{array}
$$

$$
\mathcal{M}\left(\left\{I_{i j}\right\}, p, q\right) \equiv \sum_{i} \sum_{j} i^{p} j^{q} I_{i j}
$$

とし, 画像 $\left\{I_{i j}\right\}$ に拈ける $i, j$ それぞれについての $p$, $q$ 次モーメントを表す。つまり $I_{\mathrm{C}}$ と $J_{\mathrm{c}}$ は距離值で重 み付けされた画像 $\left\{d_{i j}\right\}$ の重心位置となる.腕や脚な どに相当する狭いシルエット領域では全体的に小さな 距離值となるため, 重心位置への影響を抑制できる.

\section{2 上半身の主軸方向検出}

腕領域の除去処理のため, 距離変換画像 $\left\{d_{i j}\right\}$ にお いて身体重心の水平位置よりも上方 $\left(\left\{d_{i j}^{\prime} \mid j \geqq J_{\mathrm{c}}\right\}\right)$ に対し, 前フレームの上半身主軸（後述）を対称軸と するガウス関数を乗じる．得られた画像 $\left\{g_{i j}\right\}$ （上半 


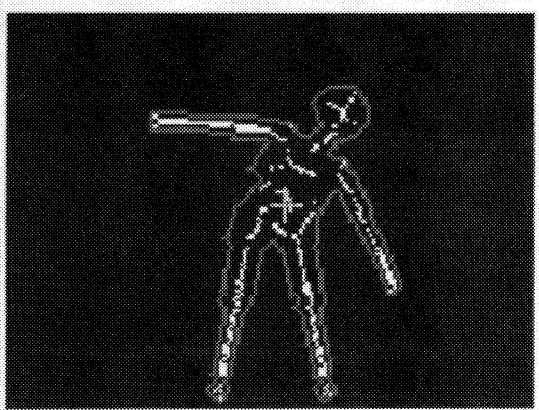

図 5 骨格画像

A skeleton image.

身距離画像と呼ぶ, 図 4) の重心を求める. $\left\{g_{i j}\right\}$ の 主軸 (PAU) 方向は (3) 式の解として得られ ${ }^{18)}, \theta$ $(|\theta|<\pi)$ は上半身の傾きとみなす.

$$
\tan ^{2} \theta+M_{\mathrm{g}} \tan \theta-1=0
$$

ただし

$$
M_{\mathrm{g}}=\frac{\mathcal{M}\left(\left\{g_{i j}\right\}, 2,0\right)-\mathcal{M}\left(\left\{g_{i j}\right\}, 0,2\right)}{\left.\mathcal{M}\left(\left\{g_{i j}\right\}, 1,1\right)\right)}
$$

である. $\left\{g_{i j}\right\}$ の重心点を通り，傾きが $\theta$ の直線を上 半身主軸と呼ぶ。

\section{3 特徵点の検出}

シルエット画像 $\left\{f_{i j}\right\}$ において身体重心点（3.1節 参照）からラス夕走查し, 最初に発見される輪郭（境 界）画素を開始点として境界線追跡を行う。なお境界 線上の画素を 1-画素，それ以外を0-画素とする 2 值画 像を輪郭画像と呼ぶことにする。ここで仮頭頂点とし て, 上半身主軸から最短距離, かつ上半身重心よりも 上方に位置する輪郭点を選ぶ。

(1) 足先点

身体重心点の算出に用いた距離変換画像の極大值を 求めることにより，図５に示すような骨格画像を作成 する。寿身（身体重心の垂直位置より下方）かつ左 （右）半身（身体重心点の水平位置を中心として左あ るいは右側）に存在する骨格の端点の中から「身体重 心点からの距離（図 6 参照）が最大」である端点を足 先点として選ぶ.

\section{(2) 手先点}

輪郭上で仮頭頂点から足先点までに相当する輪郭を， 図 7 に示すように画素数比 $l_{\mathrm{h}}: m_{\mathrm{h}}: n_{\mathrm{h}}$ の各セグメン トに分割し，中央セグメントを手先点の候補セグメン 卜とする。なお $l_{\mathrm{h}}, m_{\mathrm{h}}, n_{\mathrm{h}}$ は経験的に定めるが， 1:2:2 等の值を与えるだけでほぼすべての人物像に対して有 効である.

候補セグメントにおいて重直位置が最高（手先候補

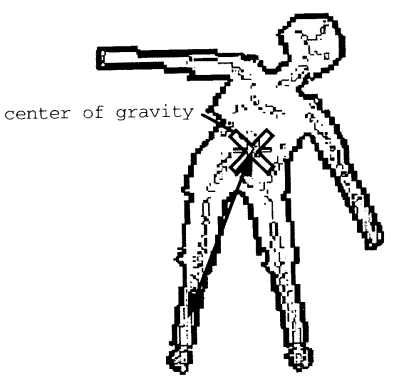

図 6 足先点の検出 Detection of an end of foot.

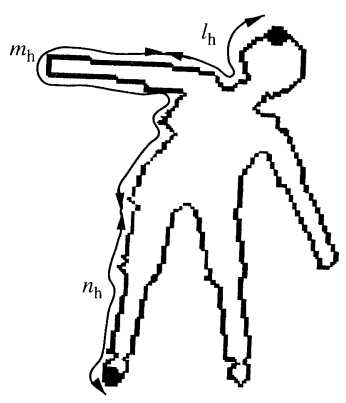

図 7 手先点の候補セグメント Candidate segment for an end of hand.

点 a）抢よび最低の点（手先候補点 b) と，身体重心 からの水平距離が最長の点（手先候補点 $\mathbf{c}$ ）を選ぶ. そして以下の条件を順に評価し, 最初に条件を満たす 候補点を手先点とする.

(a) 手先候補点 $\mathbf{a}$ の垂直位置 $>$ 仮頭頂点の垂直 位置 $-T_{1}$

（b）手先候補点 $\mathbf{b}$ の垂直位置 $<$ 身体重心の垂直 位置 $+T_{1}$

（c）手先候補点 $\mathbf{c}$ の水平位置 $<$ 身体重心の水平 位置 $+T_{2}$

(d) 候補セグメントの終端点

ここで $T_{1}, T_{2}$ はそれぞれシルエットの外接矩形の高 さによって定まる定数である.

(3) 頭頂点

輪郭上で仮頭頂点から手先点までに相当する輪郭を 画素数比 $l_{\mathrm{p}}: m_{\mathrm{p}}: n_{\mathrm{p}}$ のセグメントに分割し, 中央の セグメントを頭頂点の候補とする。そして上半身主軸 までの距離が最短である点を首位置とし，左右の首位 置に挟まれている輪郭の 2 等分点を頭頂点とする。手 先点検出の場合と同様に $l_{\mathrm{p}}, m_{\mathrm{p}}, n_{\mathrm{p}}$ は経験的に求めた 定数である. 


\section{4. 肘および膝関節位置の推定}

3 章で述べた特徴点だけでは, 人物の姿勢推定処理 としては不充分であり, 肘と膝の位置情報も重要であ る.しかし,これらの部位は輪郭において明確な形状 特徵を備えておらず, 輪郭の形状を解析するだけでは 検出が困難な部位である. 各関節の状態をエネルギー 関数で表現し, 拘束条件を与えて関節の角度を決定す

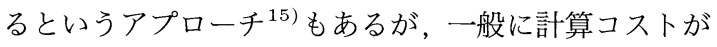
かかるため実時間処理は難しい.

本論文では, GA を利用して, あらかじめ学習サン プルにより特徵点と肘および膝の関係を求めておき, 姿勢推定において 3 章の方法により検出された特徴点 を関節位置として変換する。

\subsection{GA による推定式の導出}

$\mathrm{GA}^{13) 16)}$ では対象問題の解の候補は, 遺伝子型とし て染色体で 1 次元的に表現する. まず染色体の初期集 団を乱数的に発生させ, 評価関数に応じた選択淘汰・ 交叉・突然変異の遺伝的操作を行いながら, 並列的に 解の探索を進めて行く.

本論文では, 肘および膝の関節位置を 3 章で述べた 特徵点（身体重心, 頭頂, 手先, 足先）の位置座標の 線形結合式で表現する，その結合式の係数を集団中の 各個体の遺伝子として割り当て, GAにより推定誤差 を最小化するような係数の組合せを探索する．膝（肘） の位置を $x_{i}$, 推定される位置を $\hat{x}_{i}$ とするときの適応 度 (評価関数) $f$ を, 推定誤差 $x_{i}-\hat{x}_{i}$ の平均值 $\bar{e}$ と 誤差の分散の和の逆数として定義する.

$$
\begin{aligned}
& \frac{1}{f}=\bar{e}+\frac{1}{k} \sum_{i=1}^{k}\left(x_{i}-\hat{x}_{i}-\bar{e}\right)^{2} \\
& \text { ただし } \bar{e}=\frac{1}{k} \sum_{i=1}^{k} x_{i}-\hat{x}_{i}
\end{aligned}
$$

\section{2 肘関節}

身体重心点 $\left(x_{\mathrm{g}}, y_{\mathrm{g}}\right)$, 頭頂点 $\left(x_{\mathrm{p}}, y_{\mathrm{p}}\right)$, 手先点 $\left(x_{\mathrm{h}}, y_{\mathrm{h}}\right)$, 足先点 $\left(x_{\mathrm{f}}, y_{\mathrm{f}}\right)$ の各位置の加重線形和を 用いて（5）式のように肘の位置 $\left(x_{\mathrm{e}}, y_{\mathrm{e}}\right)$ を表現する. なお各部位は $\tilde{x}=x-x_{g}$ のように身体重心からの相 対位置で表している。前述のように,(5) 式の係数 $C_{i}$ をGAにより推定する。

$$
\begin{aligned}
\tilde{x}_{\mathrm{e}}= & C_{1}\left(x_{\mathrm{h}}-x_{\mathrm{p}}\right)+C_{2}\left(y_{\mathrm{h}}-y_{\mathrm{p}}\right) \\
& +C_{3} \tilde{x}_{\mathrm{h}}+C_{4} \tilde{y}_{\mathrm{h}}+C_{5} \\
\tilde{y}_{\mathrm{e}}= & C_{6}\left(x_{\mathrm{h}}-x_{\mathrm{p}}\right)+C_{7}\left(y_{\mathrm{h}}-y_{\mathrm{p}}\right) \\
& +C_{8} \tilde{x}_{\mathrm{h}}+C_{9} \tilde{y}_{\mathrm{h}}+C_{10}
\end{aligned}
$$

\section{3 膝関節}

手先点から足先点までの輪郭において, 身体重心と 足先の垂直位置を 2 等分した位置に存在する輪郭点 $\left(x_{1}, y_{1}\right)$ を探索しておく.これに，身体重心 $\left(x_{\mathrm{g}}, y_{\mathrm{g}}\right)$, 頭 $\left(x_{\mathrm{p}}, y_{\mathrm{p}}\right)$, 足先 $\left(x_{\mathrm{f}}, y_{\mathrm{f}}\right)$ を加えた各位置の加重線形 和を用いて次式のように膝の位置 $\left(x_{\mathrm{k}}, y_{\mathrm{k}}\right)$ を表現し， GA により係数 $W_{i}$ を推定する.

$$
\begin{aligned}
\tilde{x}_{\mathrm{k}}= & W_{1} \tilde{x}_{\mathrm{p}}+W_{2} \tilde{y}_{\mathrm{p}}+W_{3} \tilde{x}_{\mathrm{f}}+W_{4} \tilde{y}_{\mathrm{f}} \\
& +W_{5} \tilde{x}_{1}+W_{6} \tilde{y}_{1}+W_{7} \\
\tilde{y}_{\mathrm{k}}= & W_{8} \tilde{x}_{\mathrm{p}}+W_{9} \tilde{y}_{\mathrm{p}}+W_{10} \tilde{x}_{\mathrm{f}}+W_{11} \tilde{y}_{\mathrm{f}} \\
& +W_{12} \tilde{x}_{1}+W_{13} \tilde{y}_{1}+W_{14}
\end{aligned}
$$

\section{5. 実験結果と考察}

\section{1 実験システム}

本提案手法をワークステーション (SGI 社 Indy $\mathrm{R} 4400 / 150 \mathrm{MHz})$ 上に実装した。対象とする熱画像は 赤外線カメラ ((株) Nikon サーマルビジョン LAIRD3) により撮影した. 本赤外線カメラは $-20 \sim 50^{\circ} \mathrm{C}$ の観 測範囲を有し, 雑音等価温度差は $27^{\circ} \mathrm{C}$ 黒体において $0.15^{\circ} \mathrm{C}$ 以下の性能を持ち, 焦点距離 $27 \mathrm{~mm}$ のレンズ を装着している. 本赤外線カメラにより撮像された熱 画像は水平方向 160 画素 $\times$ 垂直方向 120 画素の解像 度で, 温度值（画素値に相当）は 8 ビットにて計算機 へと入力される。

\section{2 特徵点抽出実験結果}

まず， 3 次元 $\mathrm{CG}$ 人体モデル（200 頂点）によるシ ミュレーション実験を行った。すなわち, CG モデル を正面に正投影して合成した画像を用いて，3 章で述 べた検出処理の実験を行った。

実験の結果を図 8 に示す.上半身主軸の傾斜角は $75^{\circ}$ 程度まで検出できることがわかった。仮頭頂位置 の妥当性は上半身主軸角の検出可能範囲に依存してお り, 仮頭頂の誤検出は手先点や頭頂点の検出結果にも 影響する。また足先を大きく上げている姿勢について も検出が可能であった.

同様に, 実熱画像に対する実験結果を図 11 に示す. 同図左と中央の列がそれぞれ入力熱画像と特徵点の検 出結果である. 図中の小さな四角形が特徵点の推定位 置を表しており，推定が正しく行われていることが明 らかになった。

本推定法では単眼画像から得られるシルエット輪郭 の解析を用いているため，両手を身体の前で交差した り, 手先が胴体と重なるなどの姿勢は正しく検出する ことができない.しかし,すべての特徵点が身体部位 同士の自己遮蔽のない状態であれば推定が可能である. 


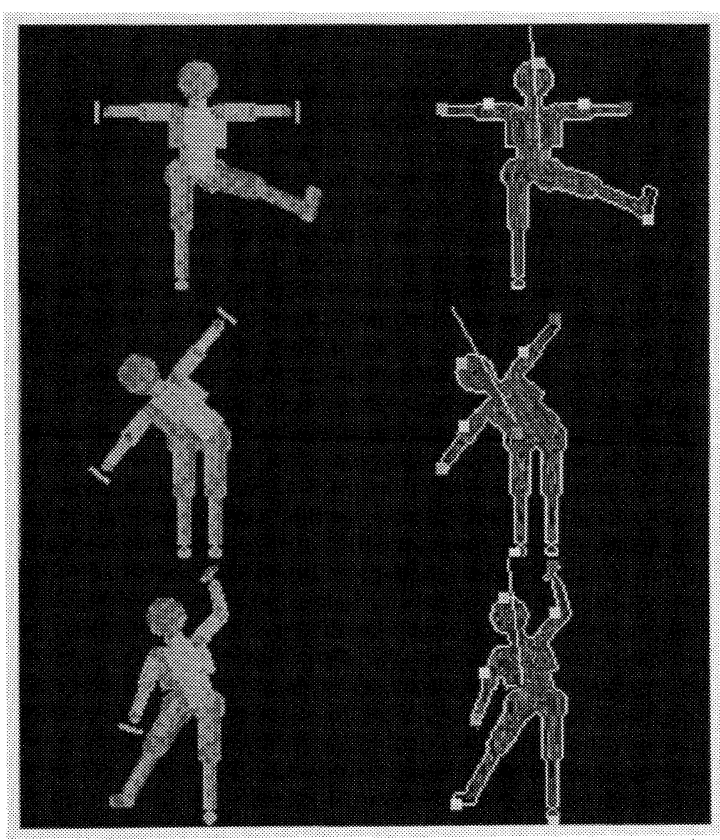

図 8 特徵点検出のシミュレーション結果

Detected significant points (target images are generated by using the 3 -D human body model).

\section{3 肘・膝位置の推定結果}

関節位置推定の有効性を確認するため以下に述べる ような実験を行った。

まず，GAによる学習処理のため「腕を曲げる」「腕 を上げる」「屈伸をする」「横にステップを踏み出す」 「足を上げる」等の肘や膝の動きを中心とした一連の 動作を赤外線カメラにより撮影した. 次にマニュアル にて肘と膝の位置を入力し，これを目標值として GA により（5）,(6) 式の係数 $C_{i}, W_{i}$ を求めた. GA の各 パラメータは以下の通りである。

・個体数：2000

-世代数：3000

- 交差確率：0.02

- 突然変異率：0.003

そして評価のために（5)，(6) 式に GA で求めた係 数と姿勢情報を代入して肘および膝の位置推定を行い, 実測值との誤差を調べた。その結果を図 9 と図 10 に 示す．図中のグラフの実線は実測値を，破線は本手法 による推定值を表している．図に見られるように誤差 は平均で 1〜2 pixel の範囲に収まっており，肘・膝と も実測值に良く近似していることがわかる. $180 \mathrm{~cm} の$ 身長の人物が画像垂直サイズの $2 / 3$ の大きさに撮像さ れていると仮定すれば 1 画素は約 $2 \mathrm{~cm}$ に相当するこ とから, 誤差は最大で $4 \mathrm{~cm}$ 程度になる. 計算機の処理
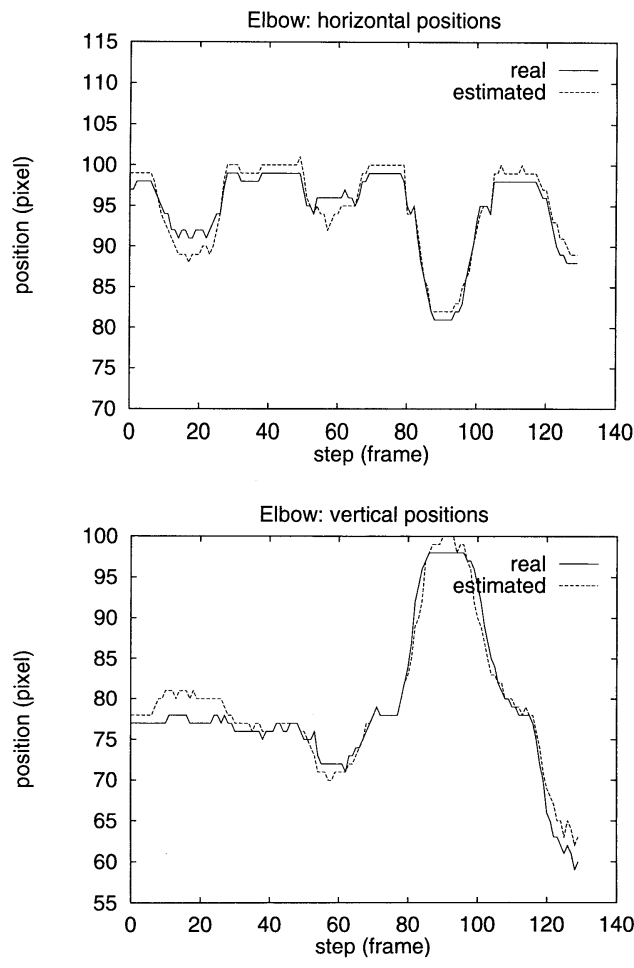

図 9 肘関節の位置推定結果

Estimation results of an elbow joint position.
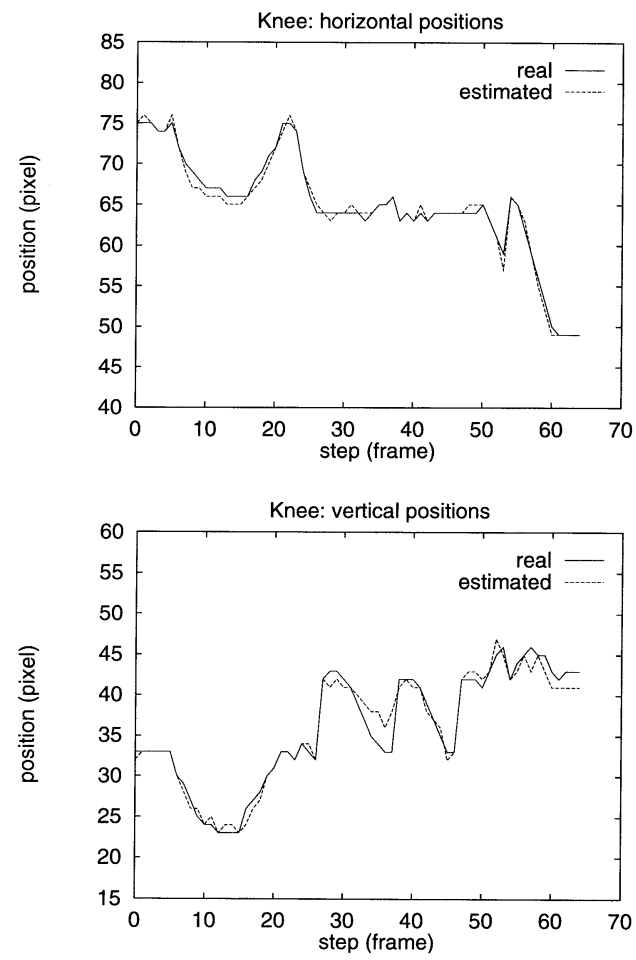

図 10 膝関節の位置推定結果

Estimation results of a knee joint position. 


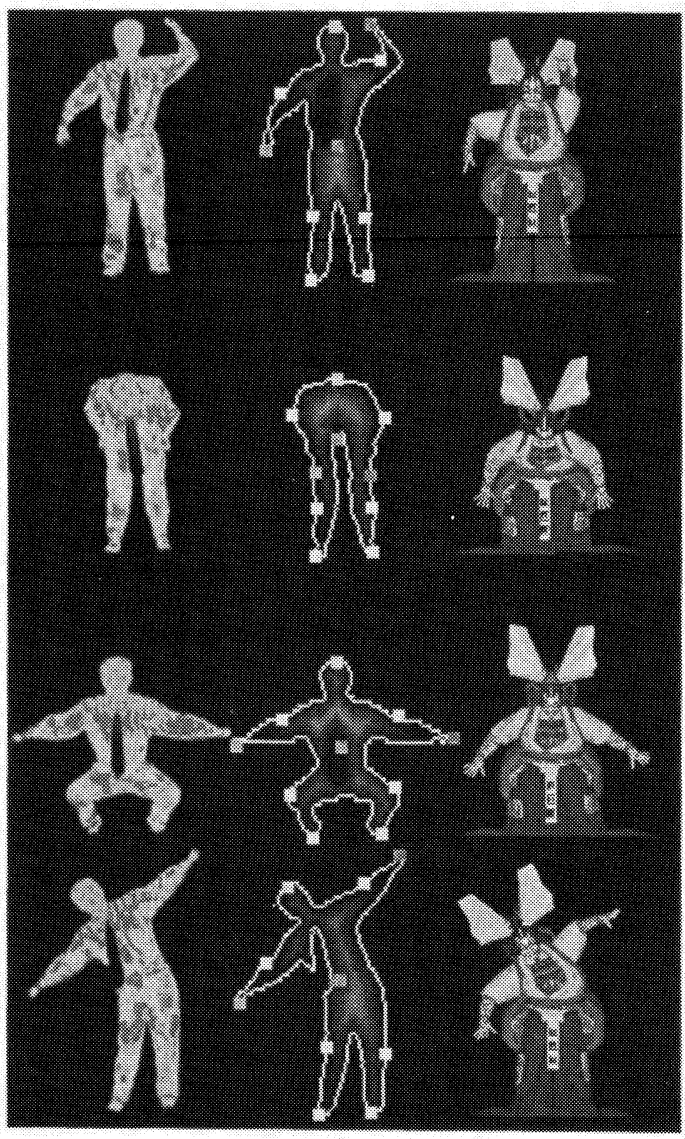

図 11 姿勢推定結果と CG モデルによる姿勢再現 Experimental results and reproduced Kabuki characters.

速度が向上すれば実時間性を保ったまま，画像の空間 分解能を高く設定することが可能となり，推定精度の 向上が期待できる。また実熱画像に対しても図 11 に 示されるように正しく推定が行われている.

\section{4 デモンストレーション}

本手法の評価抢よび応用として, SIGGRAPH 96 Digital Bayouにおいてインタラクティブデモンスト レーション17)を行った。これは人物の表情や動作が, コンピュータグラフィックスで再現される仮想歌舞伎 役者キャラクタに実時間で反映するというものであ る1).デモンストレーションにおいて多数の人物（大 人から子供まで）による姿勢推定の実演が行われ，本 推定法は問題なく動作した。この結果は，3 章で述べ た特徵点の検出のために必要な画素数比 $\left(l_{\mathrm{h}}: m_{\mathrm{h}}: n_{\mathrm{h}}\right.$ 等）のような人物像に関する経験的な定数の有効性を 示すものである。また，人物の背景は一様でなく，照 明もほとんどなく薄暗い状態であったにも関わらず,
本方式による姿勢検出は実時間に近い速度で安定に動 作した。ただし，スカートなどの熱伝導率の低い着衣 の対象人物に対する姿勢推定については不正確な場合 があった。

姿勢推定結果と併せて再現された歌舞伎役者のキャ ラクタの例を図 11 に示す。括辞儀のように上体を前 方に曲げた 3 次元的な姿勢も再現されているが，対象 人物がカメラの光軸方向に移動しないという拘束条件 下では, 画像上で身体重心から頭頂点までの距離が短 くなれば上体を前方に曲げていると解釈できるからで ある。

処理速度は 15〜20 フレーム/秒となり，実時間に近 付いておりレスポンスも良好であった。応用として ヴァーチャルリアリティなどのインタラクティブな環 境においても実用的な速度が達成できたと思われる。

従来手法の Pfinder ${ }^{12)}$ では同等の計算機において 10 フレーム/秒の処理速度となって扔り, 本推定法は これを上回っている.Pfinderでは背景の差分処理を 行うことで人物シルエットを求めているため, 背景と 同系色の服装や影を伴う場合に正しいシルエットが得 られないと考えられる。したがって，照明や服装条件 に対する頑健性が本手法に比べて低い，本手法は照明 条件には基本的に依存しないため, 極端な例として完 全な暗闇でも適用可能である。また，衣服と背景の色 彩には特別な制約を必要としないという特徵がある.

\section{6. む す び}

熱画像を用いて, 人物全身像の姿勢を実時間で推定 することが可能な手法を提案した，本手法では，まず 熱画像から人物のシルエットを抽出した後，その輪郭 をヒューリスティックスを用いて解析し，手先等の特 徵点を検出する。次に GA に基づく学習により, 検出 された特徵点の位置から, 肘および膝の関節位置を推 定する。実験により，実時間に近い速度で安定な姿勢 推定が可能であることを示した。また本手法は一般の CCD カメラ等を使用する場合と比較して背景・照明条 件の制限を緩和できる。また，モデルマッチングを必 要としないので複雑な人物モデルが不要であり，簡易 なキャリブレーションだけで任意の人物への適用が可 能である.今後は体の回転等の 3 次元姿勢の推定へと 拡張していくとともに，より柔軟な服装条件への対応 が課題である.

本研究を進めるにあたり,ご指導いただきました (株) ATR 知能映像通信研究所酒井会長に感謝いたし ます。また，有益なご討論，ご助言をいただいた第一 研究室の皆椂佗感謝致します。 


\section{〔参 考 文 献〕}

1) J. Ohya, K. Ebihara, J. Kurumisawa and R. Nakatsu, "Virtual Kabuki Theater: Towards the Realization of Human Metamorphosis Systems", Proc. of 5th IEEE International Workshop on Robot and Human Communication, pp.416421 (1996)

2) A. Pentland: "Automatic Extraction of Deformable Part Models", International Journal of Computer Vision, 4, pp.107-126 (1990)

3) A. Pentland and S. Sclaroff: "Closed-form Solutions for Physically Based Shape Modeling and Recognition", IEEE Trans. on PAMI, 13, 7, pp.715-129 (1991)

4) D. Terzopoulos and D. Metaxas: "Dynamic 3D Models with Local and Global Deformations: deformable superquadrics", IEEE Trans. on PAMI, 13, 7, pp.703-714 (1991)

5) Y. Kameda, M. Minoh and K. Ikeda: "Three Dimensional Pose Estimation of an Articulated Object from Its Silhouette Image", Proc. of Asian Conference on Computer Vision, pp.612-615 (1993)

6) A. Pentland and B. Horowitz: "Recovery of Nonrigid Motion and Structure", IEEE Trans. on PAMI, 13, 7, pp.730742 (1991)

7）亀田, 美濃, 池田：“シルエット画像からの関節物体の姿勢 推定法”, 信学論 (D-II), J79-D-II, 1, pp.26-35 (Jan. 1996)

8) Z. Chen and H. Lee: "Knowledge-guided Visual Perception of 3-D Human Gait from a Single Image Sequence", IEEE Trans. on SMC, 22, 2, pp.336-342 (1992)

9) K. Rohr: "Incremental Recognition of Pedestrians from Image Sequences”, Proc. IEEE CVPR, pp.8-13 (1993)

10) J. Ohya, F. Kishino: "Human Posture Estimation from Multiple Images Using Genetic Algorithm", Proc. 12th ICPR, pp.750-753 (1994)

11) D. Gavrila, L. Davis: "3-D Model-based Tracking of Humans in Action: a Multi-view Approach", Proc. CVPR'96, pp.73-80 (1996)

12) C. Wren, A. Azarbayejani, T. Darrel, A. Pentland: "Pfinder: Real-Time Tracking of the Human Body", Proc. of the 2nd International Conference on Automatic Face and Gesture Recognition, pp.51-56 (1996)

13) D. Goldberg: Genetic Algorithm in search, optimization, and machine learning, Addison-Wesley (1989)

14）高木, 鳥脇, 田村, “別冊 O Plus E 画像処理アルゴリズムの 最新動向”, 新技術コミュニケーションズ, pp.84-107 (1986)

15）栄藤, 岸野: “ステレオ輪郭像を入力とした物体の一般化円筒複 合体による記述”, 信学論 (D-II), J73-D-II, 9, pp.1402-1412 (Sep. 1990)

16）北野: “遺伝的アルゴリズム”, 人工知能学会誌, 7, 1, pp.26-37 (Jan. 1992)

17) K. Ebihara, J. Kurumisawa, J. Ohya, F. Kishino, R. Nakatsu: "Virtual Kabuki System", SIGGRAPH 96 Visual Proceedings, p.87 (1996)

18）田村他：“コンピュー夕画像処理入門”, 総研出版 (1985)

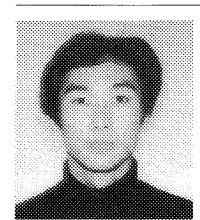

小导れしょういちろう

岩澤昭一郎 1994 年, 成蹊大学工学部電 気電子工学科卒業. 1996 年, 同大大学院修士 課程修了. 現在, 同大大学院博士課程在学中. 1996 1997 年, ATR 知能映像通信研究所研 修研究員.ヒューマンインタフェース, コン ピュータグラフィックス, コンピュータビジョ ンなどの研究に従事.工学修士.

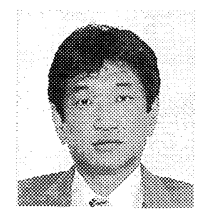

海老原一之 1982 年, 金沢工業大学工学 部情報処理工学科卒業。1984 年, 日本ビク 夕一 (株)に入社. テレビ研究所に拀いて文字 放送，ゴーストキャンセラ等ディジタル映像 信号処理の研究に従事. 1993 年, (株) ATR 通信システム研究所, 現在, (株) ATR 知能 映像通信研究所研究員, 顔画像の表情検出・ 再現の研究に従事. 正会員.

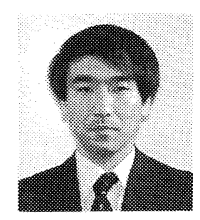

大谷 淳 1977 年, 東京大学工学部精 密機械工学科卒業。1979 年, 同大大学院修士 課程修了。同年, NTT 横須賀電気通信研究 所入所. 以来, コンピュータビジョン, フル カラー記録等の研究に従事. 1988 年より 1 年 間, 米国メリーランド大学客員研究員. 1992 年, (株) ATR 通信システム研究所に出向. 以来, 臨場感通信会議のシステム化や要素技 術に従事. 現在, (株) ATR 知能映像通信研 究所第一研究室室長. 工学博士.

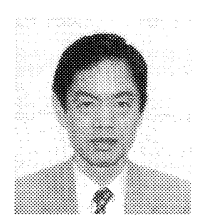

なが口上うへい

中津 良平 1969 年, 京都大学工学部電 子工学科卒業. 1971 年, 同大大学院修士課 程修了。同年, NTT 武蔵野電気通信研究所 入所. 1980 年, 横須賀電気通信研究所. 主 として音声認識の基礎研究, 応用研究に従 事. 1991 年, NTT 基礎研究所研究企画部長, 1992 年, NTT 基礎研究所情報科学研究部長. 1995 年より, ATRに移り, 現在, (株) ATR 知能映像通信研究所代表取締役社長. マルチ メディア要素技術の研究及びマルチメディア 技術を応用した通信方式の研究などに従事。 工学博士.

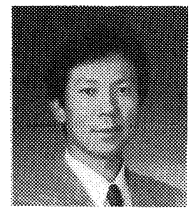

森島繁生 1982 年, 東京大学工学部電 子工学科卒業. 1984 年, 同大大学院修士課 程修了. 1987 年, 同大大学院博士課程修了. 同年, 成蹊大学工学部電気工学科専任講師。 1989 年, 同大助教授, 現在に至る. 1994 年 より 1 年間, トロント大学コンピュータサイ エンス学部客員教授, 音声信号処理, 画像処 理, 音声と画像の知的符号化などの研究に従 事. 工学博士. 正会員. 